\title{
Effect of organic sources of minerals on fat-corrected milk yield of dairy cows in confinement
}

\section{Tiago Antonio Del Valle ${ }^{1}$, Elmeson Ferreira de Jesus ${ }^{2}$, Pablo Gomes de Paiva ${ }^{2}$, Vitor Pereira Bettero' ${ }^{2}$, Filipe Zanferari', Tiago Sabella Acedo ${ }^{3}$, Luis Fernando Monteiro Tamassia ${ }^{3}$, Francisco Palma Rennó ${ }^{1}$}

\footnotetext{
${ }^{1}$ Universidade de São Paulo, Faculdade de Medicina Veterinária e Zootecnia, Departamento de Nutrição e Produção Animal, Pirassununga, SP, Brasil. 2 Universidade Estadual Paulista "Júlio de Mesquita Filho", Faculdade de Ciências Agrárias e Veterinárias, Departamento de Zootecnia, Jaboticabal, SP, Brasil.

${ }^{3}$ DSM Produtos Nutricionais Brasil S. A., São Paulo, SP, Brasil.
}

\begin{abstract}
This study evaluated the effects of organic and inorganic sources of minerals in diets for mid-lactation dairy cows on milk yield and composition, intake and total apparent digestibility of dry matter and nutrients, blood parameters, microbial protein synthesis, and energy and protein balances. Twenty Holstein cows averaging $146.83 \pm 67.34$ days in milk and weighing $625.30 \pm 80.37 \mathrm{~kg}$ were used. The experimental design was a crossover. Diets were composed of corn silage (50\%), ground grain corn, and soybean meal, differing with regard to the sources of trace minerals, plus an organic and inorganic mix. The organic mineral source increased milk fat and fat-corrected milk yield without changing milk yield, intake, or total apparent digestibility. Blood parameters, microbial protein synthesis, and energy and protein balances were not affected by the sources of minerals. Organic sources of minerals improve milk fat yield without affecting other parameters.
\end{abstract}

Key Words: Holstein, milk fat, mineral nutrition, organic mineral

\section{Introduction}

To avoid deficiency of trace minerals, mineral supplementation has been recommended as an important nutritional strategy to maintain production, reproduction, and health of dairy cows (Spears, 1996), since these are important in vital functions such as blood synthesis, structure of hormones, vitamins synthesis, reproductive function, formation of enzymes, and immune system integrity (NRC, 2001). Trace minerals are those that although essential for normal body functions, are required in a very small amount in feeding. This group includes cobalt, copper, iodine, iron, manganese, molybdenum, selenium, zinc, and chromium (NRC, 2001).

As animal productivity increased in the last years, there was an increase in the requirements and interest for more effective animal feeding strategies. This has led to the development of a specific area of study focused on the effects of the structure of minerals on their retention and relationship with health and performance of dairy cows (Nocek et al., 2006; Siciliano-Jones et al., 2008).

Received September 17, 2014 and accepted February 10, 2015 Corresponding author: francisco.renno@usp.br http://dx.doi.org/10.1590/S1806-92902015000300004

Copyright (@) 2015 Sociedade Brasileira de Zootecnia. This is an Open Access article distributed under the terms of the Creative Commons Attribution Non-Commercial License, which permits unrestricted non-commercial use, distribution, and reproduction in any medium, provided the original work is properly cited.
Trace minerals have been supplemented in the form of inorganic compounds such as sulfates. Sulfates are associated in normal conditions and dissociated when solubilized in water. Minerals dissociated in the reticulum-rumen, omasum and abomasum can interact with digestion compounds, becoming insoluble and indigestible, and excreted in feces (McDonald et al., 1996; Spears, 2003). Polyphenols and some specific carbohydrates can alter the minerala-bsorption process. In addition, some minerals have a mutual antagonism, such as iron, manganese, and cobalt (NRC, 2001).

The effects of organic minerals on productive performance of lactating cows kept in confinement, in tropical regions, are not fully established and have been discussed in recent years. In these conditions, dairy cows are more likely to suffer heat stress, which, according to Kadzere et al. (2002), reduces dry matter intake, limiting the intake of trace minerals. Heat stress increases energy requirement and accelerates metabolism, leading to malnutrition, since higher trace mineral requirements are not considered in the current diet-formulation programs.

Rabiee et al. (2010), in a meta-analytic study, demonstrated increase in fat and protein, and milk yield and improved reproductive rates with organic source of trace minerals. The results observed in different studies have, however, been variable, especially depending on the supplementation period, mineral source used, environmental conditions, and requirement of animals. 
Cope et al. (2009) reported a $1.4 \mathrm{~kg} \cdot \mathrm{day}^{-1}$ increase in milk yield of cows when they received organic zinc sources as compared with inorganic sources, at the level recommended by NRC (2001). On the other hand, studies have found that milk yield does not increase with the use of sources of organic trace minerals (Defrain et al., 2009; Hackbart et al., 2010; Nemec et al., 2012).

We hypothesized that replacing inorganic with organic sources of minerals in diets for mid-lactation cows increases milk yield without changing milk composition, intake and digestibility of dry matter and nutrients, energy and protein balances, and microbial protein synthesis.

\section{Material and Methods}

The Ethics Committee of the School of Veterinary Medicine and Animal Science of the Universidade de São Paulo, under protocol number 3057/2012, approved the experimental procedures. The trial was conducted from September 18th to October 29th, 2012. Twenty Holstein cows with $125.83 \pm 67.34$ days in milk and $625.30 \pm 80.37 \mathrm{~kg}$ of BW at the beginning of the trial were housed in individual $17.5 \mathrm{~m}^{2}$ pens with sand beds and forced ventilation.

The animals were randomly allocated to receive one of two experimental diets. Diets were formulated according to the recommendations suggested by NRC (2001), as follows: inorganic mineral (IM) - diet with the inclusion of inorganic trace mineral plus a sulfur mix; organic mineral $(\mathrm{OM})$ - diet with the inclusion of organic trace mineral plus a sulfur mix. The organic mineral sources were carbo-aminophospho-chelates of zinc, copper, selenium, chromium, manganese, cobalt, iron, and sulfur, produced by DSM Produtos Nutricionais Brasil S.A, Brazil. The experimental design was a crossover, with each experimental period lasting 21 days: $14 \mathrm{~d}$ for adaptation and $7 \mathrm{~d}$ for sampling. Diets (Table 1) and fresh water were provided ad libitum throughout the experimental period.

Diets were fed twice daily, at $07.00 \mathrm{~h}$ and $13.00 \mathrm{~h}$, with daily adjustments to supply 105 to $110 \%$ of the expected intake. Samples of feed and refusals were collected throughout the sampling period and stored at $-20{ }^{\circ} \mathrm{C}$ for subsequent analysis.

From the 16th to 18th days of each experimental period, fecal samples were collected twice daily, after the morning and afternoon milking, forming a composite sample per animal for each period. Samples of the feeds, orts and feces were analyzed for dry matter (method 930.15; AOAC, $2000)$, crude protein $(\mathrm{N} \times 6.25$; method 984.13; AOAC, 2000), ether extract (method 920.39; AOAC, 2000), aciddetergent fiber and lignin (method 973.18; AOAC, 2000), ash (method 942.05; AOAC, 2000), neutral detergent fiber and neutral detergent fiber corrected for ash, and protein using $\alpha$-amylase and without addition of sodium sulfite (Mertens, 2002).

The samples of the diet (supplied and refusals) were also evaluated for neutral detergent insoluble crude protein and acid detergent insoluble crude protein, according to the methods described in the NRC (2001). The total digestible nutrients (TDN) were estimated using the Weiss (1999) methodology.

Indigestible acid-detergent fiber (iADF) was used as internal marker to estimate fecal excretion and apparent digestibility of nutrients. Samples of feeds, orts and feces were pre-dried at $65^{\circ} \mathrm{C}$ in a forced-air woven and processed in a Wiley mill with $2 \mathrm{~mm}$ sieve. These samples were placed in bags of non-woven fabric (100 g. $\left.\mathrm{m}^{-2}\right)$ following the recommendation of a maximum of $20 \mathrm{mg}$ of dry sample $\mathrm{cm}^{-2}$ (Nocek, 1988) and incubated in the rumen of two Holstein cows previously adapted to a high-concentrate diet for a period of $288 \mathrm{~h}$, according to the technique described by Casali et al. (2008).

After removal, the bags were washed in running water, dried in an oven and subjected to acid detergent treatment

Table 1 - Ingredients and chemical composition of the experimental diets

\begin{tabular}{|c|c|c|}
\hline \multirow{2}{*}{ Item } & \multicolumn{2}{|c|}{ Experimental diet } \\
\hline & IM & OM \\
\hline \multicolumn{3}{|l|}{ Ingredient $\left(\mathrm{g} \mathrm{kg}^{-1}\right)$} \\
\hline Ground grain corn & 235.1 & 235.1 \\
\hline Soybean meal & 123.0 & 123.0 \\
\hline Raw whole soybeans & 120.0 & 120.0 \\
\hline Inorganic $\operatorname{mix}^{1}$ & 22.0 & - \\
\hline Organic $\operatorname{mix}^{2}$ & - & 22.0 \\
\hline Corn silage & 500.0 & 500.0 \\
\hline \multicolumn{3}{|l|}{ Chemical composition } \\
\hline Dry matter ${ }^{3}$ & 617.7 & 617.7 \\
\hline Organic matter ${ }^{4}$ & 949.5 & 949.5 \\
\hline Crude protein ${ }^{4}$ & 164.9 & 164.9 \\
\hline Ether extract ${ }^{4}$ & 46.6 & 46.6 \\
\hline $\mathrm{Ash}^{4}$ & 50.5 & 50.5 \\
\hline Neutral detergent fiber ${ }^{4}$ & 383.4 & 383.4 \\
\hline $\mathrm{NDFn}^{4}$ & 361.3 & 361.3 \\
\hline Acid detergent fiber ${ }^{4}$ & 203.8 & 203.8 \\
\hline Lignin $^{4}$ & 27.2 & 27.2 \\
\hline Non-fibrous carbohydrate ${ }^{4}$ & 354.6 & 354.6 \\
\hline Total digestible nutrients & 774.7 & 774.7 \\
\hline
\end{tabular}

IM - inorganic mineral diet; OM - organic mineral diet; NDFn - protein-corrected neutral detergent fiber.

${ }^{1}$ Each $\mathrm{kg}$ contains $99 \mathrm{~g}$ of $\mathrm{Ca} ; 42 \mathrm{~g}$ of $\mathrm{P} ; 45 \mathrm{~g}$ of $\mathrm{Mg} ; 20 \mathrm{~g}$ of $\mathrm{K} ; 123 \mathrm{~g}$ of Na; $18 \mathrm{~g}$ of S; $14 \mathrm{mg}$ of Co; $500 \mathrm{mg}$ of Cu; $28 \mathrm{mg}$ of I; 1,050 mg of Fe; 1,400 mg of Mn; 18 $\mathrm{mg}$ of Se; $2,800 \mathrm{mg}$ of $\mathrm{Zn} ; 80 \mathrm{mg}$ of biotin; 200,000 IU of vitamin A; 40,000 IU of vitamin D3; 1,200 IU of vitamin E; $600 \mathrm{mg}$ of monensin; $420 \mathrm{mg}$ of F.

${ }^{2}$ Each kg contains $99 \mathrm{~g}$ of $\mathrm{Ca} ; 42 \mathrm{~g}$ of $\mathrm{P} ; 45 \mathrm{~g}$ of $\mathrm{Mg} ; 20 \mathrm{~g}$ of $\mathrm{K} ; 123 \mathrm{~g}$ of $\mathrm{Na} ; 18 \mathrm{~g}$ of S; $14 \mathrm{mg}$ of Co; $500 \mathrm{mg}$ of Cu; $28 \mathrm{mg}$ of I; $1,050 \mathrm{mg}$ of Fe; $1,400 \mathrm{mg}$ of Mn; 18 $\mathrm{mg}$ of Se; $800 \mathrm{mg}$ of $\mathrm{Zn} ; 80 \mathrm{mg}$ of biotin; 200,000 IU of vitamin A; 40,000 IU of vitamin D3; 1,200 IU of vitamin E; $600 \mathrm{mg}$ of monensin; $420 \mathrm{mg}$ of $\mathrm{F}$.

${ }^{3} \mathrm{~g} \mathrm{~kg}^{-1}$ as fed.

${ }^{4} \mathrm{~g} \mathrm{~kg}^{-1} \mathrm{DM}$. 
(Mertens, 2002), in an Ankon ${ }^{\circledR}$ Analyzer, obtaining the indigestible acid detergent fiber.

Cows were mechanically milked twice daily at $06.00 \mathrm{~h}$ and $16.00 \mathrm{~h}$, and the milk production was weighed daily for the last seven days of each experimental period. From the 16th to 18th days of each period, milk samples, proportional to two daily milking yields, were collected and composited for analyses. Milk yields were corrected for the fat content of $3.5 \%$, according to Sklan et al. (1994). Fresh milk samples were analyzed for crude protein, fat, lactose and total solids, according to the methodologies described by Kaylegian et al. (2006).

Blood samples were collected on the 15th day of each experimental period by puncturing a coccygeal vein or artery, before the morning feeding. The samples were centrifuged at $800 \mathrm{x} \mathrm{g}$ for $10 \mathrm{~min}$, and the serum was collected and stored at $-20{ }^{\circ} \mathrm{C}$ until the analyses. The analyses were performed with commercially available colorimetric kits (glucose: cat. no. K-082; total cholesterol: cat. no. K-083; HDL cholesterol: cat. no. K-015; total protein: cat. no. K-031; albumin: cat. no. K-040; urea: cat. no. K-056; AST: cat. no. K-048; and GGT: cat. no. K-080; Bioclin ${ }^{\circledR}$, Belo Horizonte, Brazil). Readings were determined with a semi-automatic spectrophotometer (SBA 200, CELM ${ }^{\circledR}$, São Caetano do Sul, Brazil).

The daily urine volume was estimated from the concentration of creatinine $\left(\mathrm{mg} \mathrm{L}^{-1}\right)$ in spot samples obtained on the 16th and 17th days of each experimental period, collected four hours after the morning feeding. The creatinine concentrations were analyzed with a biochemical colorimetric kit (kinetic creatinine: cat. no. K-067, Bioclin, Belo Horizonte, Brazil) in a semi-automatic spectrophotometer (SBA 200, CELM, São Caetano do Sul, Brazil), and a daily creatinine excretion rate of $24.05 \mathrm{mg} \mathrm{kg}^{-1}$ of body weight was assumed (Chizzotti et al., 2008). The concentration of uric acid in urine (uric acid stable liquid: cat. no. K-052, Bioclin, Belo Horizonte, Brazil) was determined in a semi-automatic spectrophotometer (SBA 200, CELM, São
Caetano do Sul, Brazil) and allantoin in urine and milk were also determined (Fujihara and Yamaguchi, 1978). Excretion of allantoin and uric acid was considered total excretion of purine derivates. Microbial protein synthesis was estimated from these excretions in accordance with the method of Chen and Gomes (1992). The energy and protein balances were estimated according to NRC (2001) equations.

The data were subjected to analysis of normality of residuals and later to analysis of variance using the MIXED procedure of SAS (Statistical Analysis System, version 9.0), according to the following statistical model:

$$
Y_{i j k}=\mu+\alpha_{i}+\beta_{j}+\varepsilon_{i j k}
$$

in which $Y_{i j k}=$ dependent variable; $\mu=$ overall mean; $\alpha_{i}=$ fixed effect of the $i$-th experimental diet; $\beta_{j}=$ fixed effect of the $j$-th experimental period; and $\varepsilon_{i j k}=$ residual error. The presented means were corrected by LSMEANS in the same procedure, and the Kenward Rogers method was used to correct the degrees of freedom. An $\alpha=0.05$ significance level was adopted for all analyzed data.

\section{Results and Discussion}

Higher fat-corrected milk $(\mathrm{P}<0.05)$ and fat yield $(\mathrm{P}=0.05)$ were observed in the animals fed organic mineral as compared with those fed inorganic mineral. Milk yield, despite not having been influenced by the diets, showed a numerical difference of $0.63 \mathrm{~kg}$ per day, which, associated with a numerical increase of $1.4 \mathrm{~g}$ per $\mathrm{kg}$ in fat content, led to a $0.08 \mathrm{~kg}$ increase per day in fat yield $(\mathrm{P}<0.05)$ (Table 2$)$.

Increase in fat-corrected milk is directly related to an increase in the milk fat content with the use of sources of organic minerals. This increase suggests an improvement in the efficiency of energy use, probably due to the greater preparation of the enzyme apparatus to metabolize it. As described by Spears (1996), increased bioavailability, due to the greater stability of the molecules, and less antagonism between the mineral sources, can inhibit subclinical manifestations of deficiencies. For example, copper is

Table 2 - Performance of dairy cows fed inorganic and organic sources of minerals

\begin{tabular}{|c|c|c|c|c|c|}
\hline \multirow{2}{*}{ Variable } & \multicolumn{2}{|c|}{ Experimental diet } & \multirow{2}{*}{ Mean } & \multirow{2}{*}{ SEM } & \multirow{2}{*}{ P-value } \\
\hline & IM & $\mathrm{OM}$ & & & \\
\hline \multicolumn{6}{|c|}{$\mathrm{kg} \mathrm{day}^{-1}$} \\
\hline Milk yield & 32.06 & 32.79 & 32.43 & 0.86 & 0.296 \\
\hline $3.5 \%$ fat-corrected milk & 34.87 & 36.44 & 35.66 & 0.80 & 0.044 \\
\hline Fat & 1.29 & 1.37 & 1.33 & 0.03 & 0.050 \\
\hline Protein & 0.98 & 1.03 & 1.01 & 0.03 & 0.096 \\
\hline \multicolumn{6}{|c|}{$\mathrm{g} \mathrm{kg}^{-1}$} \\
\hline Fat & 40.6 & 42.0 & 41.3 & 1.11 & 0.308 \\
\hline Protein & 30.6 & 31.4 & 31.0 & 0.50 & 0.216 \\
\hline
\end{tabular}

IM - inorganic mineral diet; OM - organic mineral diet; SEM - standard error of the mean. 
a component of enzymes such as cytochrome oxidase, necessary for electron transport during aerobic respiration. Iron is an important component of heme proteins, such as hemoglobin and myoglobin, acting in oxygen transport. Selenium is a component of the glutathione peroxidase enzyme, exerting antioxidant activity. Zinc is a component of many metalloenzymes such as copper-zinc superoxide dismutase, carbonic anhydrase, alcohol dehydrogenase, carboxypeptidase, alkaline phosphatase, and RNA polymerase, which affects the metabolism of carbohydrates, proteins, lipids, and nucleic acids (NRC, 2001).

Cope et al. (2009) observed a $1.4 \mathrm{~kg} \mathrm{day}^{-1}$ increase in milk yield of cows averaging $35 \mathrm{~kg} \mathrm{day}^{-1}$ when these received zinc from organic sources as compared with inorganic sources at the NRC (2001) level. In the same study, when the supplementation was at a lower level than recommended, the source had no effect. Nemec et al. (2012) evaluated the substitution of inorganic sources of zinc, manganese and copper for organic sources in the feeding of early-lactating dairy cows averaging $40 \mathrm{~kg} \mathrm{day}^{-1}$ and found no effect of the source on milk yield, despite the reduction in dry matter intake. Hackbart et al. (2010) observed no effect of mineral source in diets for early-lactation dairy cows on feed intake and milk yield of high-producing dairy cows.

Rabiee et al. (2010), in a meta-analysis evaluating the effect of replacing inorganic sources with organic sources of trace minerals, reviewed 20 studies and found an increase of $0.93,0.04$ and $0.03 \mathrm{~kg} \mathrm{day}^{-1}$ in milk, fat and protein yields, respectively. The mechanisms by which this response occurs are unknown. The authors attribute these responses to multiple factors, resulting from the improved bioavailability of trace minerals.

Replacing inorganic with organic sources of minerals did not change the intake or digestibility of dry matter and nutrients (Table 3). Other studies have shown that organic sources of trace minerals have no effect on the dry matter intake (Spears and Kegley, 2002; Wright and Spears, 2004;
Vázquez-Añón et al., 2007; Cope et al., 2009; Hackbart et al., 2010). However, Malcolm-Callis et al. (2000) reported a reduction of dry matter intake in finishing steers with increasing zinc levels in the diet $\left(20,100\right.$, and $200 \mathrm{mg} \mathrm{kg}^{-1}$ DM). Evidence suggests that reduction in intake has been much more associated with toxic effects of high doses of trace elements such as zinc than the mineral source used.

Few studies have results of total apparent digestibility of dry matter and nutrients with organic mineral sources used in the feeding of dairy cows. Salvador et al. (2008) did not observe any effect of the mineral source on the apparent total tract digestibility of dry matter and nutrients in dairy cows fed diets with corn and citrus pulp as energy sources. There was also no effect in this study on the digestibility (Table 3), indicating that this is not the process by which animals increase their fat-corrected milk yield.

The concentrations of glucose, urea, total cholesterol, HDL cholesterol, total protein and albumin in the blood, as well as AST and GGT activities were not affected by the mineral source in the diet $(\mathrm{P}>0.05)$ (Table 4).

Cortinhas et al. (2012) studied the effect of replacing inorganic with organic sources of zinc, copper and selenium in diets for lactating cows 60 days before to 80 days after partum and observed similar blood concentration of glucose, total protein, albumin, total cholesterol, HDL cholesterol, and urea. No effect of trace mineral source on the activities of AST and GGT was observed, like in the present study. This suggests that the mineral source of the diet did not change steroid metabolism and there are no toxic effects on hepatocytes.

Nitrogen and energy balances can be affected by the relationship among intake, milk yield, and excretion. It is difficult to observe any statistical differences in these variables previously mentioned with the few differences obtained in this study. The results for $\mathrm{N}$ and energy balances as well as microbial protein synthesis were also not affected by the mineral source (Table 5).

Table 3 - Intake and digestibility of dairy cows fed inorganic and organic sources of minerals

\begin{tabular}{|c|c|c|c|c|c|}
\hline \multirow{2}{*}{ Variable } & \multicolumn{2}{|c|}{ Experimental diet } & \multirow{2}{*}{ Mean } & \multirow{2}{*}{ SEM } & \multirow{2}{*}{ P-value } \\
\hline & IM & $\mathrm{OM}$ & & & \\
\hline \multicolumn{6}{|c|}{ Intake $\left(\mathrm{kg} \mathrm{day}^{-1}\right)$} \\
\hline Crude protein & 3.57 & 3.70 & 3.64 & 0.08 & 0.391 \\
\hline Ether extract & 1.05 & 1.08 & 1.06 & 0.02 & 0.402 \\
\hline NDF & 7.57 & 7.91 & 7.74 & 0.17 & 0.316 \\
\hline Crude protein & 0.6764 & 0.6823 & 0.6793 & 0.0096 & 0.750 \\
\hline Ether extract & 0.7934 & 0.7818 & 0.7876 & 0.0076 & 0.444 \\
\hline NDF & 0.5882 & 0.5817 & 0.5851 & 0.0091 & 0.759 \\
\hline
\end{tabular}

IM - inorganic mineral diet; OM - organic mineral diet; SEM - standard error of the mean; NDF - neutral detergent fiber. 
Table 4 - Plasma metabolites of dairy cows fed inorganic and organic sources of minerals

\begin{tabular}{|c|c|c|c|c|c|}
\hline \multirow{2}{*}{ Variable } & \multicolumn{2}{|c|}{ Experimental diet } & \multirow{2}{*}{ Mean } & \multirow{2}{*}{ SEM } & \multirow{2}{*}{ P-value } \\
\hline & IM & $\mathrm{OM}$ & & & \\
\hline \multicolumn{6}{|c|}{$m g \mathrm{dL}^{-1}$} \\
\hline Glucose & 78.30 & 75.65 & 76.98 & 1.49 & 0.323 \\
\hline Total cholesterol & 176.30 & 182.14 & 179.38 & 5.89 & 0.620 \\
\hline HDL cholesterol & 91.13 & 86.69 & 88.91 & 7.26 & 0.727 \\
\hline Urea & 42.05 & 38.00 & 40.03 & 1.79 & 0.262 \\
\hline \multicolumn{6}{|c|}{$\mathrm{g} \mathrm{L}^{-1}$} \\
\hline Total protein & 26.82 & 24.72 & 25.77 & 1.31 & 0.433 \\
\hline Albumin & 3.59 & 3.45 & 3.52 & 0.08 & 0.354 \\
\hline \multicolumn{6}{|c|}{$\mathrm{U} \mathrm{L}^{-1}$} \\
\hline Aspartate aminotransferase & 66.50 & 61.10 & 63.80 & 2.34 & 0.260 \\
\hline Gamma-glutamyl transferase & 33.06 & 32.30 & 32.69 & 2.08 & 0.941 \\
\hline
\end{tabular}

IM - inorganic mineral diet; OM - organic mineral diet; SEM - standard error of the mean; HDL cholesterol - high-density lipoprotein.

Table 5 - Nitrogen and energy balances and microbial protein synthesis of dairy cows fed inorganic and organic sources of minerals

\begin{tabular}{|c|c|c|c|c|c|}
\hline \multirow{2}{*}{ Variable } & \multicolumn{2}{|c|}{ Experimental diet } & \multirow{2}{*}{ Mean } & \multirow{2}{*}{ SEM } & \multirow{2}{*}{ P-value } \\
\hline & IM & $\mathrm{OM}$ & & & \\
\hline $\mathrm{N}_{\text {intake }}{ }^{1}$ & 571.16 & 592.47 & 581.81 & 12.49 & 0.392 \\
\hline NE intake ${ }^{2}$ & 34.98 & 36.22 & 35.60 & 0.76 & 0.412 \\
\hline $\mathrm{N}$ fecal ecxcretion ${ }^{1}$ & 186.05 & 189.47 & 187.76 & 7.53 & 0.811 \\
\hline $\mathrm{N}$ urinary excretion ${ }^{1}$ & 119.88 & 129.10 & 124.49 & 9.07 & 0.618 \\
\hline $\mathrm{N}$ milk excretion ${ }^{1}$ & 150.36 & 155.24 & 152.73 & 3.33 & 0.466 \\
\hline Net energy for lactation ${ }^{2}$ & 22.83 & 24.15 & 23.49 & 0.48 & 0.118 \\
\hline $\mathrm{N}$ balance ${ }^{1}$ & 114.88 & 114.79 & 114.84 & 10.59 & 0.997 \\
\hline Energy balance ${ }^{2}$ & 2.15 & 2.09 & 2.12 & 0.58 & 0.962 \\
\hline Energy efficiency ${ }^{3}$ & 71.24 & 71.99 & 71.62 & 0.53 & 0.477 \\
\hline $\mathrm{N}$ efficiency ${ }^{4}$ & 25.87 & 26.57 & 26.22 & 0.55 & 0.520 \\
\hline Al-urine & 231.23 & 233.50 & 232.33 & 14.69 & 0.933 \\
\hline $\mathrm{MicCP}$ & 1073.54 & 1094.52 & 1083.76 & 72.04 & 0.881 \\
\hline
\end{tabular}

IM - inorganic mineral diet; OM - organic mineral diet; SEM - standard error of the mean; MicCP - microbial crude protein ( $\mathrm{g}$ day ${ }^{-1}$ ); $\mathrm{AL}-\mathrm{urine}$ - alantoin concentration in urine $(\mathrm{mMol})$.

${ }^{1} \mathrm{~g} \mathrm{day}^{-1}$.

2 Mcal day ${ }^{-1}$

${ }^{3} \mathrm{kcal} 100 \mathrm{kcal}^{-1}$.

${ }^{4}$ (NEL+NEG)/DEI; (kcal 100) kcal-1, where: NEL - net energy for lactation; NEG - net energy for gain; DEI - digestible energy intake.

The synthesis of microbial protein was investigated in order to relate the sulfur source and the potential effects of sulfur amino acids synthesis, such as methionine, to the milk protein yield. NRC (2001) considers methionine the major limiting amino acid for milk protein yield, in diets containing soybean meal as the primary protein source. The inclusion of an organic sulfur source did not affect the synthesis of microbial protein, although it has shown a tendency to increase milk protein yield. Changes in the composition of microbial protein, not evaluated in this study, with increased sulfur amino acids supply could justify the effects of OM diet on performance.

Hackbarth et al. (2010) reported that a possible response to supplementation with organic minerals requires a long time to lead to effective biological results. Nocek et al. (2006) reported that feeding sources of organic trace minerals to dairy cows for two lactations provides greater productive and reproductive performance in the second lactation, when they provided $100 \%$ of the requirements established by the NRC (2001).

\section{Conclusions}

The use of organic minerals increases the fat-corrected milk yield and the milk fat content without changing dry matter intake, suggesting higher efficiency in the use of energy for milk production.

\section{Acknowledgments}

The authors thank Universidade São Paulo and the Research Laboratory of Dairy Cattle for providing all the physical structure necessary for this study, and DSM Produtos Nutricionais Brasil S.A. 


\section{References}

AOAC - Association of Official Analytical Chemistry. 2000. Official methods of analysis. 17th ed. AOAC Iternational, Arlington, VA.

Casali, A. O.; Detmann, E.; Valadares Filho, S. C.; Pereira, J. C.; Henriques, L. T.; Freitas, S. G. and Paulino, M. F. 2008. Influência do tempo de incubação e do tamanho de partículas sobre os teores de compostos indigestíveis em alimentos e fezes bovinas obtidos por procedimentos in situ. Revista Brasileira de Zootecnia 37:335-342.

Chen, X. B. and Gomes, M. J. 1992. Estimation of microbial protein supply to sheep and cattle based on urinary excretion of purine derivatives - an overview of the technical details. Rowett Research Institute, Bucksburn, Aberdeen, UK.

Chizzotti, M. L.; Valadares Filho, S. C.; Valadares, R. F. D.; Chizzotti, F. H. M. and Tedeschi, L. O. 2008. Determination of creatinine excretion and evaluation of spot urine sampling in Holstein cattle. Livestoock Science 113:218-225.

Cope, C. M.; Mackenzie, A. M.; Wilde, D. and Sinclair, L. A. 2009. Effects of level and form of dietary zinc on dairy cow performance and health. Journal of Dairy Science 92:2128-2135.

Cortinhas, C. S.; Freitas Júnior, J. E.; Naves, J. R.; Porcionato, M. A. F.; Silva, L. F. P.; Rennó, F. P. and Santos, M. V. 2012. Organic and inorganic sources of zinc, copper and selenium in diets for dairy cows: intake, blood metabolic profile, milk yield and composition. Revista Brasileira de Zootecnia 41:1477-1483.

DeFrain, J. M.; Socha, M. T.; Tomlinson, D. J. and Kluth, D. 2009. Effect of complexed trace minerals on the performance of lactating dairy cows on a commercial dairy. The Professional Animal Scientist 25:709-715.

Fujihara, S. and Yamaguchi, M. 1978. Effects of allopurinol 4hydroxypyrazolo $(3,4-d)$ pyrimidine on metabolism of allantoin in soybean plants. Plant Physiology 62:134-138.

Hackbart, K. S.; Ferreira, R. M.; Dietsche, A. A.; Socha, M. T.; Shaver, R. D.; Wiltbank, M. C. and Fricke, P. M. 2010. Effect of dietary organic zinc, manganese, copper, and cobalt supplementation on milk production, follicular growth, embryo quality, and tissue mineral concentrations in dairy cows. Journal of Animal Science 88:3856-3870.

Kadzere, C. T.; Murphy, M. R.; Silanikove, N. and Maltz, E. 2002. Heat stress in lactating dairy cows: a review. Livestock Production Science 77:59-91.

Kaylegian, K. E.; Houghton, G. E.; Lynch, J. M.; Fleming, J. R. and Barbano, D. M. 2006. Calibration of infrared milk analyzers: Modified milk versus producer milk. Journal of Dairy Science 89:2817-2832.

Malcolm-Callis, K. J.; Duff, G. C.; Gunter, S. A.; Kegley, E. B. and Vermeire, D. A. 2000. Effects of supplemental zinc concentration and source on performance, carcass characteristics, and serum values in finishing beef steers. Journal of Animal Science 78:2801-2808.

McDonald, M.; Mila, I. and Scalbert, A. 1996. Precipitation of metal ions by plant polyphenols: Optimal conditions and origin of precipitation. Journal of Agricultural and Food Chemistry 44:599-606.

Mertens, D. R. 2002. Gravimetric determination of amylase-treated neutral detergent fiber in feeds with refluxing beakers or crucibles: collaborative study. Journal of AOAC International 85:1217-1240.

Nemec, L. M.; Richards, J. D.; Atwell, C. A.; Diaz, D. E.; Zanton, G. I. and Gressley, T. F. 2012. Immune responses in lactating Holstein cows supplemented with $\mathrm{Cu}, \mathrm{Mn}$, and $\mathrm{Zn}$ as sulfates or methionine hydroxy analogue chelates. Journal of Dairy Science 95:4568-4577.

Nocek, J. E. 1988. In situ and other methods to estimate ruminal protein and energy digestibility. Journal of Dairy Science 71:2051-2069.

Nocek, J. E.; Socha, M. T. and Tomlinson. D. J. 2006. The effect of trace mineral fortification level and source on performance of dairy cattle. Journal of Dairy Science 89:2679-2693.

NRC - National Research Council. 2001. Nutrient requirements of dairy cattle. 7th ed. Academic Press, Washington, DC.

Rabiee, A. R.; Lean, I. J.; Stevenson, M. A. and Socha, M. T. 2010. Effects of feeding organic trace minerals on milk production and reproductive performance in lactating dairy cows: A meta-analysis. Journal of Dairy Science 93:4239-4251.

Salvador, S. C.; Pereira, M. N.; Santos, J. F.; Melo, L. Q. and Chaves, M. L. 2008. Resposta de vacas leiteiras à substituição total de milho por polpa cítrica e à suplementação com microminerais orgânicos I: Consumo e digestão. Arquivo Brasileiro de Medicina Veterinária e Zootecnia 60:682-690.

Siciliano-Jones, J. L.; Socha, M. T.; Tomlinson, D. J. and DeFrain, J. M. 2008. Effect of trace mineral source on lactation performance, claw integrity, and fertility of dairy cattle. Journal of Dairy Science 91:1985-1995.

Sklan, D.; Kaim, M.; Moallem, U. and Folman, Y. 1994. Effect of dietary calcium soaps on milk yield, body weight, reproductive hormones, and fertility in first parity and older cows. Journal of Dairy Science 77:1652-1660.

Spears, J. W. 1996. Organic trace minerals in ruminant nutrition. Animal Feed Science and Technology 58:151-163.

Spears, J. W. 2003. Trace mineral bioavailability in ruminants. Journal of Nutrition 133:1506-1509.

Spears, J. W. and Kegley, E. B. 2002. Effect of zinc source (zinc oxide vs zinc proteinate) and level on performance, carcass characteristics, and immune response of growing and finishing steers. Journal of Animal Science 80:2747-2752.

Vázquez-Añón, M.; Peters, T.; Hampton, T.; McGrath, J. and Huedepohl, B. 2007. Case study: Supplementation of chelated forms of zinc, copper, and manganese to feedlot cattle with access to drinking water with high sulfate concentration. The Professional Animal Scientist 23:58-63.

Weiss, W. P. 1999. Energy prediction equations for ruminant feeds. p.176-185. In: Proceedings of the Cornell Nutrition Conference for Feed Manufacturers. Cornell University, Ithaca.

Wright, C. L. and Spears, J. W. 2004. Effect of zinc source and dietary level on zinc metabolism in Holstein calves. Journal of Dairy Science 87:1085-1091. 